\title{
HAEMATOXIC EFFECTS FOLLOWING INGESTION OF NIGERIAN CRUDE OIL AND CRUDE OIL POLLUTED SHELLFISH BY RATS
}

\author{
E.U. EYONG*'; I. B. UMOH ${ }^{1}$; P. E. EBONG ${ }^{1}$; M.U. ETENG ${ }^{1}$; A. B. ANTAI ${ }^{2}$ \\ and A. O. AKPA ${ }^{3}$ \\ Departments of Biochemistry ${ }^{1}$, Physiology ${ }^{2}$ and Anatomy ${ }^{3}$, Faculty of Basic Medical Sciences, College \\ of Medical Sciences, University of Calabar, Calabar
}

\begin{abstract}
Summary: The haematological effects following ingestion of shellfish exposed to crude oil polluted water or the pollutant perse were investigated in albino Wistar rats. Feeding of four groups of rats for 28 days duration with two reference casein or shellfish protein control diets (Group A and B), and two test diets (Group C and D) supplemented at varying levels with shellfish which had been previously exposed to crude oil polluted water and the oral gavaging with crude oil at the rate of 3,6 and $9 \mathrm{ml} / \mathrm{kg}$ body weight per day to three groups (groups II, III and IV respectively) of rats for 7 days duration resulted in changes in packed cell volume (PCV), red blood cell (RBC) and white blood cell (WBC) counts, and haemoglobin concentration $(\mathrm{Hb})$ of rats. Group C and D respectively fed $10 \%$ and $20 \%$ polluted shellfish diets recorded significant $(\mathrm{P}<0.05)$ decreases in PCV and RBC counts while $\mathrm{Hb}$ concentration and WBC counts increased. Groups II, III and IV gavaged with varying doses of crude oil recorded significant $(\mathrm{P}<0.05-0.01)$ dose dependent decrease in PCV and RBC counts when compared to controls (group 1). Hb and WBC counts also increased for these groups but the increase was only significant for WBC counts $(\mathrm{P}<0.05)$ when compared with controls. The results suggest that the ingestion of shellfish exposed to crude oil polluted water or the polluted perse results in haematotoxicity.
\end{abstract}

Key Words: Haematological Indices, Crude Oil, Shellfish

\section{Introduction}

Crude oil exploration is the mains stay of the Nigerian economy and constitute about $90 \%$ foreign exchange earning of the nation. Apart from the financial benefits, the exploration of crude oil brings about the pollution of our environment including our waterways (rivers and streams). Hence, crude oil exposure presents a potential harzard to both aquatic terrestrial species (Shore and Douben, 1994). Generally, crude oil reaching the terrestrial and aquatic ecosystems arrives as a consequence of spillage which may result from natural seepages, offshore exploration, leakage from oil wells or from oil tankers, accidents from oil tankers, land based discharges and sabotage (Awobajo, 1981. Wardly and Smith, 1983; Jackson et al 1989).

In Nigeria the exposure of crude oil in the aquatic environment is on the increase following the several frequent spillages that have occurred in our coastal waters. Ibiebele (1986) had earlier estimated that an average of $11-54 \mathrm{mg} / 1$ of oil is dissolved in water. This deserves attention owing to the possibility of bioaccumulation and bioconcentration of crude oil component in aquatic lives, and the attendant consequences of ingesting such aquatic species. Evidence from other populations abound on the toxic injuries resulting from ingesting animals exposed to polluted water ways. Apart from this, the existence of aquatic species are threatened by the spillages. Studies by Imevbore (1980) and Ekekwe (1981) have reported reductions in species densities and diversity in Nigerian environments contaminated by oil from oil spills within the intertidal zones.

Within our rural population crude oil is orally ingested for medicinal purposes. It is claimed to be an antidote to poisoning and a cure for various gastrointestinal disturbances (Personal Communication). The ingestion of crude oil either orally or through polluted marine species represents a pathway for delivery of potential toxicants to the human system. This investigation is therefore aimed at assessing the potential haematological effects associated with the ingestion of crude oil and crude oil polluted shellfish (Egeria radiata) by rats. It is envisage that the result of this investigation may serve as a basis from 
which our population will be educated on the possible dangers associated with some of their practices.

\section{Materials and Methods Crude Oil}

The crude oil used for this study was obtained from Shell Petroleum Development Company, Port Harcourt, under permission from the Department of Petroleum, Resources, NNPC, Lagos, Nigeria. The crude oil was stored in a clean container and kept in our laboratory until required for use. The composition and physicochemical properties of the oil is presented as table 1 .

\section{Aquria and Shellfish}

Two glass tanks measuring $3 \mathrm{~m} \times 1.5 \mathrm{~m}$ fitted with air pumps (Tecax API 500, 30 AP 15) were used as aquaria. The river water in which the shellfish were kept before and during the experiments was not enriched with algae cultures, however, the tanks contained sediments from the natural habitats of the shellfish. Shellfish (Egeria radiata) were collected from Itu river, Akwa Ibom State, Nigeria. The Shellfish were conveyed in buckets containing river mud and water and transported to the laboratory. The natural habitat for the shellfish was simulated in the two separate aquariums. All shellfish were acclimatized in the laboratory for one week prior to experimentation. Each of the aquariums was filled river water to a height of $1 \mathrm{~m}$. One of the aquarium was then polluted with 50ml Bonny Light crude oil. The crude oil water medium was then constantly stirred to allow for adequate solubility of the soluble crude oil components. Further mixing was provided for by the air current from the air pumps. Shellfish was later transferred to the two tanks and allowed to inhabit this environment for one week. Gaping of the valves and total lack of response to mechanical stimulation of mantle cavity were used as criteria of death.

\section{Table 1: Composition and physical properties of Nigerian bonny light crude oil}

\begin{tabular}{|c|c|}
\hline Property of Component & Content \\
\hline API gravity $\left(20^{0} \mathrm{C}\right)$ & 33.50 \\
\hline Sulphur (wt. \%) & 0.14 \\
\hline Nitrogen (wt. \%) & 0.23 \\
\hline Nickel (mg/kg) & 5.40 \\
\hline Vanadium (mg./kg) & 1.90 \\
\hline Naphtha $^{\mathrm{a}}$ (wt. \%) & 21.50 \\
\hline Alkanes & 11.70 \\
\hline Cycloalkanes & 6.70 \\
\hline Aromatic hydrocarbons & 3.10 \\
\hline High boling fraction ${ }^{\mathrm{b}}$ (wt. \%) & 73.80 \\
\hline Saturates & 33.00 \\
\hline n-alkanes & 4.60 \\
\hline Isoalkanes & 12.50 \\
\hline Aromatic hydrocarbons & 23.70 \\
\hline Polar materials (wt. \%) & 0.40 \\
\hline Insoluble materials (wt. \%) & 2.50 \\
\hline
\end{tabular}

${ }^{a}$ Fraction boiling from $20-205^{0} C^{b}$ Fraction boiling above $205^{\circ} \mathrm{C}$

SOURCE: Department of Petroleum Resources NNPC, Lagos, Nigeria.

\section{Preparation of Experimental Diets}

Table 2 indicates the composition of the experiment diets, which were prepared according to the International Council of Nutrition Standards. The reference diet supplemented with $10 \%$ vitamin free casein as protein source served as primary control diet, while Diet II supplemented with unpolluted shellfish flesh as protein source served as secondary control diet. Diet III and IV, supplemented with $10 \%$ and $20 \%$ respectively of polluted shellfish flesh as protein sources served as the test diets. 
Haematological effect following crude oil ingestion

Table 2: Composition experimental diets

\begin{tabular}{lcccc}
\hline \multicolumn{1}{c}{ Component } & Diet I & Diet II & Diet II & Diet IV \\
\hline Corn starch (g) & 150.00 & 150.00 & 150.00 & 150.00 \\
Sucrose (g) & 571.10 & 570.00 & 570.00 & 470.00 \\
Corn Oil (g) & 50.00 & 50.00 & 50.00 & 50.00 \\
Alpha Cellulose (g) & 78.90 & 80.00 & 80.00 & 80.00 \\
Mineral mix (g) & 40.00 & 40.00 & 40.00 & 40.00 \\
Vitamin mix (g) & 10.00 & 10.00 & 10.00 & 10.00 \\
Casein (g) & 100.00 & - & - & - \\
Unpolluted shellfish & - & 100.00 & - & - \\
Polluted shellfish (g) & - & - & 100.00 & 200.00 \\
Total (g) & 1000.00 & 1000.00 & 1000.00 & 1000.00 \\
\hline
\end{tabular}

Grouping and Treatment of Animals

(a) Animals Gavaged with Bonny Light Crude Oil

Twenty adult male albino Wistar rats weighting 180-190g were randomly assigned to four groups of rats each. Group I animals, which served as control were gavaged $9 \mathrm{ml} / \mathrm{kg}$ body weight distilled water as placebo for one week duration. Group II, III and IV were orally gavaged with 3,6 and $9 \mathrm{ml} / \mathrm{kg}$ body weight of Bonny Light crude petroleum oil respectively per day for the same duration. The animals were allowed rat pellet (Pfizer Livestock Feed Limited, Aba. Nigeria) and water ad libitum. On the $8^{\text {th }}$ day the animals from each group were sacrificed using chloroform anaesthesia and blood obtained by cardiac puncture for analysis.

(b) Animal Feeding Experiment

Thirty-two growing albino Wistar rats of age twenty-one days weighing 70-80g were obtained from the animal house of the Department of Biochemistry, Faculty of Basic Medical Sciences, University of Calabar, Calabar. The animals were randomly assigned to four groups, namely: A, B, C and D each comprising 8 rats. Groups A, B. C and D were fed diets I, II, III and IV (Table 2 ) respectively for a twenty-eight days duration. Known quantities of the diets were allowed ad libitum after an average daily feed intake had been previously established during the acclimatization period. Distilled water was also allowed at will. At the end of the feeding period, the rats were anaesthetized with chloroform, dissected and blood obtained by cardiac puncture for analysis.

\section{Haematological Estimations}

The blood samples collected into heparinized sample tubes were immediately used for determination of haematological parameters. The percentage packed cell volume was determined according to the hematocrit method of Alexander and Griffiths (1993a) while the blood haemoglobin concentration in all samples were estimated according to the cyanomethaemoglobin method of Alexander and Griffiths (1993b). Total red blood cell and white blood cell counts were estimated according to the visual method of Dacie and Lewis (1975).

Estimation of Total Hydrocarbon Concentration in Tissue of Shellfish (Egeria radiata)

$3 g$ wet weight of tissue were digested in $20 \mathrm{ml}$ of alkaline methanol (5g of Potassium hydroxide, $75 \mathrm{ml}$ of methanol) and $5 \mathrm{ml}$ of $20 \%$ brine (20g of sodium chloride, $80 \%$ of distilled water). Refluxed for 1-2 hours, cooled and extracted in $15 \mathrm{ml}$ of $\mathrm{n}$-hexane. Determination of total hydrocarbon concentration was done colorimetrically at $430 \mathrm{~nm}$ using Hach spectrophotometer model DR/300.

\section{Results}

Table 3 shows the haematological indices of rats following the feeding of the various experimental diets for 28 days. There was a decrease in packed cell volume of rats fed the $10 \%$ and $20 \%$ polluted shellfish diets (group C $(37.20 \% \pm 0.84)$ and D $(36.80 \% \pm 1.10)$ respectively. The decreases in PCV were significantly different $(\mathrm{P}<0.5-0.01)$ when compared to Group A $(46.00 \% \pm 2.12)$ and Group B animals $(44.40 \% \pm 3.21)$. Similarly, there was a decrease in RBC counts in Group $\mathrm{C}$ and $\mathrm{D}$ animals. However, the decrease was only significant in Group D (483.27 x $10^{4} \pm$ $10^{4}$ cells per $\mathrm{mm}^{3}$ of blood) when compared to Groups A and B $\left(510.80 \times 10^{4} \pm 21.22 \times 10^{4}\right.$ and $508.60 \times 10^{4} \pm 26.72 \times 10^{4}$ cells per $\mathrm{mm}^{3}$ of blood respectively). There were slight increases in WBC counts in Group C and D animals. The increases were not significant ( $\mathrm{P}>0.05$ ) when compared to Group A and B animals. Similarly, the blood haemoglobin concentration of groups $\mathrm{C}$ and $\mathrm{D}$ animals were higher when compared to Group A and B.

However, the differences were not statistically significant $(\mathrm{P}>0.05)$. 
E.U. Eyong et al

Table 4 shows the haematological indices of rats gavaged with test doses of crude oil. There was a dose dependent decrease in PCV following the oral gavaging with 3, 6 and 9 $\mathrm{ml} / \mathrm{kg}$ body weight oil for 7 days duration (34.43\% \pm 3.44 for Group II, 28.61\% \pm 5.41 for Group III and 25.22\% \pm 4.06 for Group IV). This decrease was significant for all the test doses at $\mathrm{P}<.0 .05$ and $\mathrm{P}<0.01$ compared to control animals (Group I with a value of $50.20 \% \pm 2.27$ ). The RBC counts also showed dose dependent decreases in all test groups with counts of $623.22 \pm 29.76$ counts $/ \mathrm{mm}^{3}$ of blood ( $\mathrm{N} \mathrm{x} 10^{4}$ cells) in control animals and $366.63 \pm 31.72$ counts $/ \mathrm{mm}^{3}$ of blood $\left(\mathrm{N} \times 10^{4}\right)$ in Group III and $308.84 \pm 24.60$ counts $/ \mathrm{mm}^{3}$ of blood in $\left(\mathrm{N} \times 10^{4}\right)$ in Group IV. These decreases were significant for all test doses at $\mathrm{P}<0.05$ and $\mathrm{P}<0.01$ compared to control animals.
The WBC counts in all treatment groups increased significantly $(\mathrm{P}<.0 .05-0.01)$ when compared to the control animals following one week gavaging of crude oil. This increases in WBC counts was dose dependent with the animals gavaged with $9 \mathrm{~m} / \mathrm{kg}$ body weight (Group IV) recording the highest WBC counts $\left(84.27 \pm 2.94\right.$ counts $/ \mathrm{mm}^{3}$ of blood $(\mathrm{N}$ x 50 cells) in control, $102.65 \pm 4.82$ counts, $\mathrm{mm}^{3}$ of blood ( $\mathrm{N}$ x 50 cells) in Group II, $145.40 \pm 4.51$ counts $/ \mathrm{mm}^{3}$ blood ( $\mathrm{N}$ x 50 cells) in Group III, and $150.55 \pm 2.89$ counts $/ \mathrm{mm}^{3}$ of blood $(\mathrm{N} \mathrm{x}$ 50 cells) in Group IV. There were also dose dependent increases in blood haemoglobin concentration in all test groups following the oral gavaging of the crude oil $(13.21 \pm 2.03$ $\mathrm{g} / \mathrm{dl}$ in Group II, $14.35 \pm 2.70 \mathrm{~g} / \mathrm{dl}$ in Group III and $14.78 \pm \mathrm{g} / \mathrm{dl}$ in Group IV). The increases were however not significant $(\mathrm{P}>0.05)$ when compared to the control group $(12.64 \pm 1.50$ g/dI).

Table 3: Haematological indices of rats fed the experimental diets for 28 days

\begin{tabular}{cccccc}
\hline $\begin{array}{c}\text { Group } \\
(\mathrm{n}=8)\end{array}$ & Diet type & $\begin{array}{c}\text { Packed cell } \\
\text { Volume }(\%)\end{array}$ & $\begin{array}{c}\text { Red blood cell } \\
\text { count/ } \mathrm{mm}^{3} \text { of } \\
\text { blood }\left(\mathrm{N} \mathrm{x} 10^{4}\right. \\
\text { cells })\end{array}$ & $\begin{array}{c}\text { White blood cell } \\
\text { count/ } \mathrm{mm}^{3} \text { of } \\
\text { blood }(\mathrm{N} \text { x } 50 \\
\text { cells })\end{array}$ & $\begin{array}{c}\text { Haemoglobin } \\
\text { concentration } \\
\text { (g/dl) }\end{array}$ \\
\hline A & $\begin{array}{c}\text { Primary } \\
\text { control } \\
\text { Secondary } \\
\text { control }\end{array}$ & $46.00 \pm 2.12$ & $510.80 \pm 21.32$ & $84.10 \pm 0.64$ & $10.53 \pm 0.27$ \\
B & $44.40 \pm 3.21$ & $508.60 \pm 26.22$ & $85.47 \pm 3.13$ & $10.53 \pm 041$ \\
C & $\begin{array}{c}10 \% \text { Shellfish } \\
\text { Diet }\end{array}$ & $37.20 \pm 0.84^{\text {a, b, c }}$ & $497.51 \pm 23.44$ & $85.47 \pm 3.13$ & $11.31 \pm 1.04$ \\
D & $\begin{array}{c}\text { 20\% Shellfish } \\
\text { Diet }\end{array}$ & $36.80 \pm 1.10^{\text {a, b, c }}$ & $483.27 \pm 13.90^{\text {a, c }}$ & $84.55 \pm 0.86$ & $11.43 \pm 1$. \\
\hline
\end{tabular}

Results are presented as Mean $\pm S D$

${ }^{a}$ Significantly different from primary control value $(P<0.05)$

${ }^{b}$ Significantly different from primary value $(P<0.01)$

${ }^{c}$ Significantly different from secondary control value $(P<0.05)$

Table 4: Effect of oral gavaging of bonny liight Crude oil on some haematological indices in rats

\begin{tabular}{|c|c|c|c|c|c|}
\hline $\begin{array}{l}\text { Group } \\
(\mathrm{n}= \\
5)\end{array}$ & $\begin{array}{l}\text { Dose }(\mathrm{ml} / \mathrm{kg} \\
\text { body weight }\end{array}$ & $\begin{array}{l}\text { Packed cell } \\
\text { Volume (\%) }\end{array}$ & $\begin{array}{c}\text { Red blood cell count/ } \\
\mathrm{mm}^{3} \text { of blood ( } \mathrm{N} \times 10^{4} \\
\text { cells) }\end{array}$ & $\begin{array}{c}\text { White blood cell } \\
\text { count/ } \mathrm{mm}^{3} \text { of blood } \\
\text { ( } \mathrm{N} \text { x } 50 \text { cells })\end{array}$ & $\begin{array}{c}\text { Haemoglobin } \\
\text { concentration } \\
(\mathrm{g} / \mathrm{dl})\end{array}$ \\
\hline & 0 & $50.20 \pm 2.27$ & $623.22 \pm 29.76$ & $84.87 \pm 2.94$ & $12.64 \pm 1.50$ \\
\hline \multicolumn{6}{|l|}{$\begin{array}{c}\text { I } \\
\text { (contro } \\
\text { l) }\end{array}$} \\
\hline & 3 & $34.42 \pm 3.44^{\mathrm{a}, \mathrm{b}}$ & $366.63 \pm 31.72$ & $102.65 \pm 4.82^{\mathrm{a}, \mathrm{b}}$ & $13.21 \pm 2.03$ \\
\hline & 6 & $28.61 \pm 5.41^{\mathrm{a}, \mathrm{b}}$ & $325.81 \pm 35.21$ & $145.40 \pm 4.51^{\mathrm{a}, \mathrm{b}}$ & $14.35 \pm 2.70$ \\
\hline $\begin{array}{l}\text { III } \\
\text { IV }\end{array}$ & 9 & $25.22 \pm 4.06^{\mathrm{a}, \mathrm{b}}$ & $308.84 \pm 30.60^{\mathrm{a}, \mathrm{b}}$ & $150.55 \pm 2.89^{\mathrm{a}, \mathrm{b}}$ & $14.78 \pm 2.22$ \\
\hline
\end{tabular}

Results are presented as Mean $\pm S D$

${ }^{a}$ Significantly different from primary control value $(P<0.05)$

${ }^{b}$ Significantly different from primary control value $(P<0.01)$ 
Table 5: Total hydrocarbon concentration in tissues of shellfish (Egeria Radiata) exposed to crude oil polluted water

\begin{tabular}{ll}
\hline Group & Total Hydrocarbon Concentration (ppm) \\
\hline Control & $180.66 \pm 3.47$ \\
Test & $250.45 \pm 2.04^{\mathrm{a}}$ \\
\hline
\end{tabular}

The result is an average of 3 determinations

${ }^{a}$ Significantly different from control value $(\mathrm{P}<0.05)$

\section{Discussion}

The determination of haematological indices provides physiological information on the general blood picture and the reticuloendothelial system. In this study rats fed experimental diets supplemented with 10\% and 20\% shellfish exposed to crude oil polluted water (group $\mathrm{C}$ and $\mathrm{D}$ ) recorded significant decreases in PCV and RBC counts while the blood haemoglobin concentrations were slightly elevated when compared to controls. However, the WBC counts of all experimental animals were within the same range of $4200-4250$ cells per cubic mm of blood. Animals gavaged with 3, 6 and $9 \mathrm{ml} / \mathrm{kg}$ body weight of crude oil also exhibited significant dose dependent decreases in PCV and RBC counts while WBC counts were significantly increased. However, blood haemoglobin concentration was slightly elevated. These results are in agreement with previous reports by other investigators. Cody et al., (1981) reported haematological disorders evidenced by decrease in PCV and $\mathrm{RBC}$ in rats exposed to 1, 3 - dinitrobenzene. Leighton (1990) also observed decreases in PCV and an increase in corpuscular HB in rats exposed to Prudhoe Bay crude oil. D' Azevedo et al (1996) similarly observed decrease in PCV and RBC of rats treated with the hydrocarbons, benzene and xylene. Additionally, Leighton (1990) had reported severe haemolytic anaemia in mice following the ingestion of Prudhoe Bay crude oil.

The results of this investigation appear to indicate that the ingestion of crude oil either through shellfish or as raw crude oil induces anaemia.. Anaemia is defined as a state of lower than normal concentration of $\mathrm{Hb}, \mathrm{PCV}$ or RBC counts. PCV values below $30 \%$ for anaemic rats have been reported (Chen and Chang, 1981; Ifere, 1986).

The observed decreased in RBC counts may result due to increase in hemolysis mediated via the hydrocarbon components of crude oil. RBC itself is capable of metabolizing the crude oil hydrocarbons into reactive electrophiles, which apart from forming adducts with RBC, deplete the level of glutathione (GSH) in this organ, rendering it vulnerable to electrophilic attack by these electrophiles generated through the first phase of hydrocarbon metabolism. The preponderance of this species may then offer a load to the secondary metabolic transformations of which glutathione conjugation is one. This may serve to further deplete glutathione hence rendering the RBC more vulnerable to attack. The slight increase in Hb concentration observed in this study may therefore result due to the increase in haemolysis of RBC. Hb concentrations are reported to be moderately increased in haemolytic anaemia and any condition associated with rapid intrascular haemolysis and haemoglobinuria (Bolarin, 1997).

Another probable reason for the observed decrease in RBC counts may be due to perturbations of crude oil hydrocarbons on growth or differentiation inducers involved in erythropoiesis. Infact, Keller and Synder (1986) had demonstrated that the erythoid colony-forming unit (CFU) is susceptible to the cytotoxic effects of benzene. Additionally, Degowin et. al (1989) have reported that benzene activated the production of $\mathrm{PGE}_{2}$ which is known to suppress erythropoiesis especially in the low dose and acute condition. However, the exact mechanism responsible for the observed decrease in RBC counts is yet to be established. Work is however going on in our laboratory to ascertain this.

The PCV otherwise known as haematocrit is a function of RBC concentration. It represents the percentage of RBC in blood (Kiraly, 1980). Therefore, the decrease in PCV observed in this study is in agreement with the observed decrease in RBC counts. The increase in WBC counts following the gavaging of crude oil is in lined with the normal physiologic response following perception of a foreign attack by the body defense mechanisms. From our observation it is evident that ingestion of crude oil either orally or through shellfish results in toxicity targeted at the haematopoietic system. 


\section{References}

Alexander, R.R. and Grifiths, J.M. (1993a). Haematocrit In: Basic Biochemical Methods, $2^{\text {nd }}$ Ed., John Wiley and Sons, Inc. Publications, New York, pp 186 - 187.

Alexander, R.R. and Grifiths, J.M. (1993b). Haematocrit determination by the cyanomethaemoglobin method In: Biochemical Methods, $2^{\text {nd }}$ ed., John Wiley and Sons, Inc. Publications, New York, pp $186-187$.

Awobajo, S.A. (1981). An analysis of oil spill accidents in Nigeria: $1976-1980 . \quad$ In Proceedings of the Petroleum Industry and the Nigeria Environment. Nov., 19-22 1981, NNPC, PTI, Warri, Nigeria pp. 8994.

Bolarin, D.M. (1997). A Handbook of Clinical Chemistry. Nelson Publishers Limited, Illupeju, Lagos, Nigeria. 412 pp.

Chen, L.T. and Chang, P.K. (1981). Intrasplenic P.A. in normal induced anaemic rats. Am J. Haematol. 11: 403407.

Cody, T.E.; Witherup, S.; Hastings L. et al. (1981). 1, 3-Dinitrobenzene: Toxic effects invivo and invitro J. Toxicol. Environ. Health. 7:829- 847.

Dacie, J.V. and Lewis S. M (1975). Practial Haematology $\quad 5^{\text {th }} \quad$ ed., Churchill Livingstone, London, pp. 502-503.

D' Azevedo, P. A., Tannhauser, M., Tannhauser, S.I. and Barros, H.M. (1996). Haematological alterations in rats from xylene and benzene. Vet Hum. Toxicol. 38 (5): $340-344$.

Degowin, R, Fisher, P., and An, D. (1987) Differencial elaboration of Prostaglandin $\mathrm{E}_{2}$ by cells of the hemopoietic microenvironment in response to endotoxin. J. Lab. Clin. Med. 109: 679 686.
Ekekwe, E. (1981). The Funiwa-5 oil well blowout. In: proceedings of the international Seminar on the Petroleum Industry and the Nigerian Environment. 1922 Nov. 1981, NNPC, PTI, Warri, Nigeria, pp. 64-68.

Ibiebele, D.D. (1986). Point -Source inputs of petroleum waste into the Niger Delta, Nigeria. Sci. Total Environ. 52: 233-238.

Ifere, G.O. (1986). Adenosine Triphosphate Activity in red blood cells from deficient rats M.Sc Thesis, Department of Biochemistry, University of Calabar, Nigeria.

Imevbore, A.M.A. (ed) (1980). Preliminary Report on the ecological effects of the Funiwa oil well blowout. Environmental Consulting Group, Obafemi Awolowo University, Ile-Ife, Nigeria. 12 pp.

Jackson, M.H., Morris, G.P., Smith, P.G. and Grawfood, J. R. (1989). Water Resource: Quality and Pollution. Environ. Health 9: 1-22.

Keller, D.A. (1980). Haematology Problem. Am J. Med. Tech. 80: 25-27. Leighton F.A. (1990). The systemic toxicity of Prudhoe Bay Crude oil other petroleum oils to CDmice. Arch Environ Contam. Toxicol. 9 (2) :257 - 262.

Shore, R. F. and Douben, P.E. (1994). Predicting ecotoxicological impacts of environmental contaminants on terrestrial small mammals. Rev. Environ. Contam. Toxical. 13: 4989.

Wardley-Smith, J. (1983). The Dispersant Problem. Marine Pollution Bulletin, 14: 245-249.

Received: June 10, 2004

Accepted: August 11, 2004 